\title{
The Challenge of Inclusion of Children with Physical Impairment: Absenteeism in Focus-A Case Study
}

\author{
Tadesse Abera Tedla', Sintayehu Mesfin Anteneh ${ }^{2}$, Asfaw Woldekdan Nigus ${ }^{1}$, \\ Amsalu Tadie Gelaw', Mohammed Ahmed Mohammed'1, Ayenachew Beshay Tekle ${ }^{1}$ \\ ${ }^{1}$ Department of Special Needs and Inclusive Education, School of Education, University of Gondar, Gondar, \\ Ethiopia \\ ${ }^{2}$ Ministry of Education, National Educational Assessment and Examinations Agency, Addis Ababa, Ethiopia \\ Email: peace4ujesus@gmail.com, Mulerw121@gmail.com
}

Received 22 October 2015; accepted 6 November 2015; published 13 November 2015

Copyright (C) 2015 by authors and OALib.

This work is licensed under the Creative Commons Attribution International License (CC BY).

http://creativecommons.org/licenses/by/4.0/

(c) (i) Open Access

\section{Abstract}

This study was undertaken to investigate those factors that were influencing as factors of absenteeism from school for students with physical impairment in Hedar 11 Secondary School of North Gondar Zone of Amhara Regional State of Ethiopia. Five students with physical impairments were selected through available sampling technique and 8 teachers were selected from 24 teachers of the school through simple random sampling via lottery method. Questionnaire and interview were the main data collection instruments. To collect data letter of recommendation was taken from Department of Special Needs Education of School of Education of the University of Gondar and was given to the Principal of Hedar 11 Secondary School. Then, the director was cleared with the objectives of the study and he expressed his permission the study to be undertaken. And then, the selection of the teacher participants and the student participants followed. The data collected was analysed quantitatively (through, frequency, percentage and mean) and qualitatively through thematic analysis. The results demonstrated that the major absenteeism factors from school for students with physical impairments were: parents (lack of knowledge how to treat their children with physical impairment and financial problems), teachers (negative attitude, lack of professionalism in special needs education i.e. lack of knowledge on how to treat children with physical impairments), guards of the school, peers, and school related factors (such as, inflexible rule and regulation of the school, long distance between the school and the homes of the students with physical impairments, uncomfortable infrastructure of the school, lack of learning material and less support given to the students). Finally, based on the study findings relevant conclusions and recommendations were forwarded.

\section{Keywords}

Absenteeism, Students with Physical Impairment, School Accommodation for Students with Physical Impairment, Factors of Absenteeism for Students with Physical Impairment 


\section{Introduction}

\subsection{Background of the Study}

According to Ethiopia's 1994 Population and housing census, 1.85 percent of the population is with disabilities, well below the 10 percent WHO estimate that is so often used. [1] estimated that 7.6 percent of the population in Ethiopia lives with a disability (approximately 5 million). If the WHO's estimate is used, which puts people with disabilities population at 10 percent of the total population in any one country, the number of disabled persons in Ethiopia would be around 7.7 million. Ethiopia's Third Education Sector Development Programme (ESDP III) estimates that Ethiopia has about 1.7 to 3.4 million school-age children with Special Needs Education (Ministry of Education 2005 as cited in [2]). Similarly, the Special Needs Education (SNED) Programme Strategy estimates that 1.5 to 3 million learners will need special attention due to disabilities, learning difficulties, or being gifted or talented [2]. According to [3], in this country of about 30 million school-aged children, less than 1 percent of children with special needs have access to education.

However, Ethiopia has done quite well in terms of meeting Universal Primary Education targets over the last decade and is on track to achieve this goal. The Net Enrolment Ratio (NER) in the lower primary school cycle (Grade 1-4) increased from $77.5 \%$ in $2004 / 2005$ to $92.2 \%$ in 2011/2012 and in the upper cycle of primary education (Grade 5-8) from $37.6 \%$ to $48.1 \%$ during the same period. Overall, the NER for primary education (Grade $1-8$ ) increased from $77.5 \%$ in $2005 / 2006$ to $85.4 \%$ in $2011 / 2012$. The primary school attendance ratio has risen from $30.2 \%$ in $2000 / 2001$ to $64.5 \%$ in $2010 / 2011$. The increase in attendance was disproportionately higher for children from rich families at $70 \%$ compared to $52 \%$ for children from poor families. Most of these children dropout of school after grade five although dropout rates have been declining. For example, the completion rate in lower primary education rose from $69.1 \%$ in $2010 / 11$ to $73.8 \%$ in $2011 / 12$ and is expected to increase further as government accelerates implementation of interventions aimed at increasing enrolment and educational progression of children from poor families, thereby helping to break the yoke of inter-generational poverty among poor households Ministry of Finance and Economic [4].

When, we go directly to the issue of the study, student's absenteeism is a major concern for teachers. Absence creates a dead, tiresome, unpleasant classroom environment to students who come to classroom early [5] [6]. Absenteeism disturbs the dynamic teaching learning environment and adversely affects the overall wellbeing of classes [7]. In quality terms, absenteeism is a waste of educational resource, time and human potential [8] [9]. In an effort to help absentee students teach them their missed classes, teachers will be forced to take time from the class hour of attending students at different sessions [10].

It should be noted that the primary issue of chronic absenteeism is not whether to excuse absentee students or not, but absentee students will not get anything out of the excuse if they are allowed. According to [11], students with physical impairment who were absent from school suffered academically. Studies indicate that students with physical impairment who are absent have a lower achievement and may be penalized test scores [12]. Sustained absences may affect retention as it may degenerate into truancy [10] [13]. Continued loss of instruction or poor academic achievement among students with physical impairment with high absenteeism was essential characteristics of students who later dropped out of school [14]. [15] also found in a social studies course that there was a significant influence of students' level of attendance on their academic performance. [16] found further that students with better attendance not only scored higher test performance but also demonstrated more knowledge, at least of the course material, in learning. In a subsequent study, [5] reported a mandatory attendance policy which confirmed significant reduction in absenteeism and improvement in examination performance.

The researchers have noticed that there is a problem of absenteeism of students with physical disabilities in our contact with the school for the academic purpose. So, we have developed an interest to undertake research on the issue. Therefore, the main purpose of the study was to find out factors of absenteeism of students with physical impairments in Hedar 11 General Secondary School.

\subsection{Statement of the Problem}

According to [17], students who missed class on a given date were significantly more likely to respond incor- 
rectly to questions relating to material covered that day than students who were present. The same is true for students with physical impairments. [18] in his study to investigate the high number of absentees in Alliance High School and the impact of absenteeism on students' academic achievement has found out four factors for students absenteeism these were 1) characteristics of at-risk students, 2) the school circumstances that can put students at risk, 3) effects of being at-risk on student achievement, and 4) effective interventions for at-risk students. He further recommended that: a) the need to identify at-risk students based on their absenteeism as early as possible; b) the need for schools to identify in-school factors that could be addressed to discourage absenteeism, including classroom management, teaching styles, competitiveness in schools, parental involvement, aggressive counseling programs for at-risk students, consideration of cultural and language differences, a strong attendance policy, expansion of student educational opportunities through choices, and recognition of the students interest.

In short, research has shown a direct correlation between good attendance and student achievement and poor attendance has been linked to poor academic achievement [19] [20].

Currently, many students with physical impairment do not show active attendance in their education and giving in the allotted time due to certain in habiting factors. Their short comings may occur because of certain situations. That is why; the researchers developed a keen interest to do research in the area. So, those factors that make students with physical impairment absent from their classes in Hedar 11 General Secondary School will be investigated thoroughly. To meet this purpose the following research question was forwarded.

What are the factors that affect students with physical impairment to be absent from School?

\subsection{General Objectives}

The general objective of the study was to identify those factors that affect students with physical impairment to be absent from School.

\subsubsection{Specific Objectives}

The specific objectives of this study are to:

$\checkmark$ Investigate those factors that make students with physical impairment be absent from class; and

$\checkmark$ Recommend possible solutions to the school community and the concerned bodies to avoid absenteeism of students with physical impairment.

\subsection{Significance of the Study}

The results of the study will have the following contributions:

$\checkmark$ It will create awareness especially for classroom teachers, parents, and concerned stakeholders about factors that are causing absenteeism from school for students with physical impairment;

$\checkmark$ It will give an alarming bell for school community in particular and the stake holders in general to find out alternative solutions for those students with physical impairment to avoid their absenteeism from school; and

$\checkmark$ It will help other researchers as a spring board to conduct further studies on this area.

\subsection{Delimitation of the Study}

This research was delimited only to Hedar 11 General Secondary School. The study was also delimited conceptually on factors that affect those students with physical impairment to be absent from school. And, the school was selected because of its convenience to have frequent contacts as needed.

\subsection{Limitation of the Study}

There was no pilot study and reliability of the questionnaire was not checked. In fact, we did not give much attention to these issues because our study was a case study of one school and the respondents of our study were small in number.

\subsection{Operational Definitions of Terms}

Inclusion: refers to integrating students in to the regular class with sufficient provision of access to education.

Absenteeism: refers to inability of students with physical impairment to attend their classes on time due to 
different reasons.

Physical impairment: is a disability exhibited in a motor problem which limits or reduces an individual from performing the usual activity.

\section{Review of Related Literature}

\subsection{The Concept of Physical Impairment}

Different scholars defined physical impairment in different ways. According to [21] physical impairment is a disability category that comprises hindered of conditions and disease having high incidence disability.

Physical disability also defined as those where physical limitations or health problems interference with school attendance or learning to such an extent that special services, training, equipment, materials, or facilities are required. Our definition excludes children whose primary characteristics are visual or auditory impairments, although some children with physical disabilities have these deficiencies as secondary problems. Children who have physical disability may also have mental retardation, learning disabilities, emotional or behavioral disorders, communication disorder, or special gifts or talents [22].

Physical disabilities are often broken down into sub categories; the physical impaired and health impaired [22]. Furthermore, physical disabilities are problems that result from condition affecting the central nervous system or loss of limbs or other body systems and their related functions. These conditions affect the motor functions or how children use their bodies.

In short, physical impairment is a condition related to physical deformity or disability of the skeletal system and associated with motor function such as, affected muscular and skeletal system, affected central nervous system and adversely, affects children's' psychosocial, educational and their development achievements.

\subsection{Types of Physical (Orthopedic Impairment)}

\subsubsection{Cerebral Palsy}

Cerebral palsy is a group of neuromuscular disorder that results from the damage of central nervous system i.e. the brain and spinal cord before, during and after birth. The causes of cerebral palsy are injury during birth congenital cerebral defect, post natal head injury and infection undefined or other causes. Cerebral palsy may be categorized in to specific physical disability groups; spasicity, athetoid, ataxic, hypotonic, and rigged and termor [23].

\subsubsection{Poliomyelitis}

Poliomyelitis is an acute disease that inflames nerve cells of the spinal cord or brain stem and leaves a residual paralysis or muscular atrophy. It is acute communicable disease caused by the polio virus. According to described poliomyelitis as a virtual infection affecting the interior horn cells in the spinal cord and brain stem and producing a flaccid motor paralysis [24].

\subsubsection{Spinal Bifida}

Spinal bifida is congenital defect in the development of the spinal cord. It is an opening in the spinal column caused by the failure of vertebrate to fuse [23]. And it is congenital malformation of the spine characterized by lack of closure of the vertebra in to a sac at the base of the spine. There are two forms of spinal bifida. These are spinal bifida occulta which is a very mild form of a condition and spinal bifida cystic which is a very severe form of a condition [25]

\subsubsection{Epilepsy}

Epilepsy is convulsive disorder that is caused by excess firing of electrical discharges in the brain cells. Electrically the brain is unstable. Epilepsy is characterized by seizures, disturbances of movements, sensation behavior. Consciousness and chronic conditions of the central nervous system with various forms such as grandma, petitmal and psychomotor seizures are the most observed [24].

\subsubsection{Muscular Dystrophy}

Muscular dystrophy is a hereditary disorder that causes a loss of utility and progressive deterioration of the 
body's as a result of atrophy, or replacement of muscle tissue with the skeletal muscles progressively are in atrophy. According to [23], there are four forms of muscular dystrophy, namely pseudo hypertrophic, factocapulahumeral, limpdudle, and mixed dystrophy.

\subsection{Motor Skills and Mobility}

Motor skills and mobility constitute critical areas of skills development for children with physical disabilities. These skills are necessary to maintain up right postures (sitting, standing) to perform functional movements (reaching, grasping) and to move around the environment. The programming priorities for motor skills development should include developing functional movements and postures that are needed to perform classroom and school activities.(Curle1973 as cited in [24]) an appropriate positioning technique includes;

$\checkmark$ Sufficient head and trunk control to maintain an upright sitting posture in order to perform needed activities throughout the school day (attending and listening, writing using a computer or communication device, eating).

$\checkmark$ Standing and balance for assisted ambulation (using braces and crutches).

A child spastic cerebral palsy who constantly leans sideways in the wheel chair will have tremendous difficulty reaching the key board on the computer and striking the correct keys or suing the mouse. With the help from a physical therapist or occupational therapist, the teacher can learn to position the students in the wheel chair, use a slant board to move the keyboard closer to the child, and relax the child's arms and bring them forwards to reset on the keyboard.

Increasingly, children with cerebral palsy are involved in motor skill activities and attending their regular classes under the guidance of a physical therapist. These activities include swimming, dance, martial arts, horseback riding and other real life experiences. The vast majority of children with physical disabilities spend part of their days in the general education classroom. The inclusion of physical disabilities in general classroom setting is encouraged (Curle 1973 as cited in [24]).

In short, some children with physical impairment may attend neighborhood school, but they require modification of physical environment for the children to enable them interact with the physical and social world [25].

\subsection{Educational Responses to Students with Physical Disabilities}

Students with physical disabilities will need supports and services. Many students with physical disabilities will receive the majority their services in general education classroom. These students will. However, also need specific supports to address academic, functional and life skills, assistive technology, and counseling needs. The development of an individual educational planning is critical to guiding the instructional modification and to ensuring that the transition needs of the students have been addressed. Students with physical disabilities will receive solid instructional support and services that required collaboration among their teachers. And the supports focused on self advocacy and general career planning and were taught by the guidance counselor with special educational and physical and occupational therapy. This will help teachers and service providers determine the level of the child's needs and to organize their responses to meet these needs. Angina, remember that the greater the need of the child, the more intensive the service must be to meet the need [5].

\subsection{Possible Factors of Absenteeism from School of Children with Physical Impairment}

Students must be present in school in order to benefit from the academic program in its entirety [20] [27]. It is believed that regular school attendance can help ensure student academic success [27]. Class attendance is likely to be beneficial for learning, irrespective of the specific teaching mode or modes used by the instructor [28].

\subsubsection{The Economy of Parents}

The economy of a country play significant role not only for education but also for any other changes to lead a better way of living. So, the parent's ability to afford the materials available for their children with physical impairment in the school determines learning. Parents of high socio-economic status may send their children to school with the necessary instruments such as pen, pencil, paper, books, exercise books, and so on; whereas the low social-economic ones may not do the same.

Therefore, students, with poor parents are exposed for absenteeism and engaged in different labor tasks 
whenever they get before finishing their school. To this end, [24] describes that the majority of absenteeism of students with physical impairment come from poor homes, where the poor are found in areas where the school are worst, attitude of children themselves are inculcated by hopelessness, making them feel school to be a pointless waste of time. In one study in America it was found out that economical influences for students absenteeism includes employed students, single-parent homes, high mobility rates, parents who hold multiple jobs, and lack of affordable transportation and childcare [29]. [30] argued that family obligations also make some students not to go to schools. As children enter early adolescence, family responsibilities can keep them from school. In high poverty environments, young adolescent girls sometimes provide emergency day care for younger siblings or are responsible for getting younger children to school.

In short, different scholars pointed that socio-economic status of parents play a role in educating the child. The worst is, if the parents, the school community and stakeholders are not aware of this the child will fall in to the poverty trap. Even though previous research has linked students' socio-economic factors that are associated with student absences that are beyond the control of the school, educators can improve attendance, by monitoring students' attendance, encouraging personal development and building relationships with parents setting high expectations [31].

\subsubsection{Educational Level of Parents}

It is clear that the educational background of parents' have positive or negative impact or vice versa effects on the education of children with physical impairment.

When parents are not well educated they did not know the importance of education. As a result, they may not send regularly their children with physical disabilities to schools or they may not properly help their children to learn their education with regular attendance. For example, in one study in America it was found out that lack of guidance or parental supervision, domestic violence, poverty, drug or alcohol abuse in the home, lack of awareness of attendance laws, and differing attitudes toward education [29].

In short, family and peer influence have a stronger effect up on the child with physical disabilities to lean than the school itself, and home effects are more powerful than those the street outside [32]. He further, explains that if, parents the child's have little respect for education, the likelihood of the child with physical impairment absenteeism will be increased. Again, [32] gives more emphasis on parent's internet as the following: "Parental interest is also one of the greatest influences on the child's progress in school."

\subsubsection{School Related Factors}

These include school climate issues—such as school size and attitudes of teachers, other students, and principals and unit leaders and inflexibility in meeting the diverse cultural and learning styles of the students. Schools often have inconsistent procedures in place for dealing with chronic absenteeism and may not have meaningful consequences available for truant youth (e.g., out of school suspension) [29].

Williams [11] stressed that schools, their curricula, and the strength of sanctions against chronic absenteeism are also contributing causes to students' absenteeism in schools. [13] [33] concluded that lack of challenging course work and curriculum are some of the factors for student absenteeism.

Furthermore, [30] in their study found out those students who are forced to leave school, either through suspension, expulsion or being sent to an alternative school are not likely to increase their connectedness to or engagement with the school.

In short, [34] concluded that harsh school rules and regulations could cause absenteeism that is; corporal punishment, families where students prepare themselves for school and parent to work.

\subsubsection{Teacher Factors}

Teachers play a vital role in the lives of their students. Teachers can enhance the attendance of students with physical impairment by really getting to know their students and working to earn their trust through consistent, positive intervention, being a positive role model, and teaching interesting and relevant information that helps in keeping the students engaged in the learning process. Teachers must closely monitor academic programs; work at maintaining an open line of communication to students, encourage students to participate in extra curricular activities, and act immediately when the student with physical impairment become on the patterns of failures appear.

In line to this, [35] found out that the major reasons replied by students for their absenteeism were poor 
teaching (23\%), timing of the lesson (23\%) and poor quality of the lesson content (9\%). [36] also supported that students have poor or conflicting relationships with teacher will avoid school in order to avoid their teacher.

In short, we can also imagine that the negative attitudes of teachers towards the attendance of students with physical impairment can be manifested in not willing to accept their lateness from school and allow them enter class late; because they do not acknowledge that physical impairment is the cause of their absenteeism.

\section{Research Design and Methodology}

\subsection{Design of the Study}

The study has employed a descriptive survey design. In which, both quantitative and qualitative research approaches were utilized.

\subsection{Population of the Study}

There were 1230 students and 24 teachers in Hedar 11 General Secondary School. Out of these there were 5 students with physical impairments.

\subsection{Sample and Sampling techniques}

Random sampling technique was used which was simple random sampling through lottery system to select eight teachers out of 24 teachers. And available sampling technique was used for taking all students with physical impairment as their number was only 5 in the school.

\subsection{Data Collection Instruments}

Questionnaire and interview were used as the main data collection instruments. To explain more, open and closed ended questionnaire items were incorporated.

Whereas, in the interview instrument unstructured interview schedule was used for students with physical impairment, the reason why unstructured interview schedule for students with physical impairment employed was it helps to get deep information which was not possible to gather during the administration of questionnaires. Here, both the items in the questionnaire and interview after they were developed well in English they were translated to Amharic. It helped particularly the students with physical impairment to have clear understanding on how to respond.

\subsection{Procedure of Data Collection}

First, we got a letter of recommendation from the Department of Special Needs and Inclusive Education of the University of Gondar for the school to welcome us. Secondly, we have briefed to the director of the school about the objective of the study. Thirdly, discussion was held with the guidance and counseling professional in identifying the students with physical impairment. Fourthly, with the selected teachers and taken students consent of agreement was reached after they become clear with the objective of the study. Then, we enter to the study. Meanwhile, note pad and tape recorder were used in the interview sessions.

\subsection{Methods of Data Analysis}

The data was gathered through instruments such as questionnaire and interview. The qualitative data was organized, coded and was put in to thematic areas. Then, quantitative and qualitative analysis was followed. For example, on the quantitative analysis part, the data was analyzed by using frequencies, percentage and average (mean).

\subsection{Ethical Consideration}

The study was conducted in ways that protect the dignity and safety of the study participants. Participants were given 2 to 3 days to return the questionnaire in order to give them ample time to enhance the validity of the information and for not consuming their teaching and learning times. Before, interview time only interested interviewees were selected. The time and the place of interview were selected by the participants of the study them- 
selves. Finally, all responses were kept confidential and they were kept only for the academic purpose.

\section{Presentation and Analysis of the Data}

The data collected through questionnaire and interview is presented in this part. On the quantitative aspect the data is presented in frequency, percentages and average, then analysis followed while the qualitative data is presented thematically in narrative forms. Tables 1-6 are the responses of students with physical impairments whereas, Table 7 to Table 8 are the responses of teachers.

As indicated in Table 1, 5(100\%) of the students are males and the majority $4(80 \%)$ are grade 9.

Table 1. Background information of student participants.

\begin{tabular}{|c|c|c|c|c|}
\hline S. No & Item & & Frequency & $\%$ \\
\hline \multirow[t]{3}{*}{1} & Sex & Male & 5 & 100 \\
\hline & & Female & 0 & 0 \\
\hline & & Total & 5 & 100 \\
\hline \multirow[t]{3}{*}{2} & Grade level & $9^{\text {th }}$ grade & 4 & 80 \\
\hline & & $10^{\text {th }}$ grade & 1 & 20 \\
\hline & & Total & 5 & 100 \\
\hline \multirow[t]{3}{*}{3} & On set of disability & Before birth & 1 & 20 \\
\hline & & After birth & 4 & 80 \\
\hline & & Total & 5 & 100 \\
\hline \multirow[t]{4}{*}{4} & Parent's educational level & Primary complete & 4 & 80 \\
\hline & & Secondary complete & 1 & 20 \\
\hline & & Degree and above & 0 & 0 \\
\hline & & Total & 5 & 100 \\
\hline \multirow[t]{3}{*}{5} & Parent's economic status & Poor & 4 & 80 \\
\hline & & Rich & 1 & 20 \\
\hline & & Total & 5 & 100 \\
\hline
\end{tabular}

Table 2. Background information of the teacher participants.

\begin{tabular}{|c|c|c|c|c|}
\hline S. No & Items & & Frequency & $\%$ \\
\hline \multirow[t]{3}{*}{1} & Sex & Male & 6 & 75 \\
\hline & & Female & 2 & 25 \\
\hline & & Total & 8 & 100 \\
\hline \multirow[t]{4}{*}{2} & Teaching experience & 5 years & 0 & 100 \\
\hline & & 6 to 15 years & 3 & 37.5 \\
\hline & & 16 and above years & 5 & 62.5 \\
\hline & & Total & 8 & 100 \\
\hline \multirow[t]{3}{*}{3} & Felid of study & Special needs education & 0 & 0 \\
\hline & & Other fields of studies ${ }^{\mathrm{a}}$ & 8 & 100 \\
\hline & & Total & 8 & 100 \\
\hline
\end{tabular}

${ }^{a}$ Other field of studies refers to both subjects in natural and social sciences except special needs education. For example, Chemistry, Biology, History, Geography and etc. 
Table 3. Teachers as factors for absenteeism.

\begin{tabular}{|c|c|c|c|c|c|c|c|}
\hline \multirow{3}{*}{ S. No } & \multirow{3}{*}{ Item } & \multicolumn{4}{|c|}{ Response } & \multirow{2}{*}{\multicolumn{2}{|c|}{$\begin{array}{c}\text { Total } \\
\text { Response }\end{array}$}} \\
\hline & & \multicolumn{2}{|c|}{ Agree } & \multicolumn{2}{|c|}{ Disagree } & & \\
\hline & & $\mathrm{F}$ & $\%$ & $\mathrm{~F}$ & $\%$ & $\mathrm{~F}$ & $\%$ \\
\hline 1 & $\begin{array}{l}\text { I observe negative attitude of teachers towards } \\
\text { students with physical disabilities. }\end{array}$ & 3 & 60 & 2 & 40 & 5 & 100 \\
\hline 2 & I am unable to get special support from teachers. & 3 & 60 & 2 & 40 & 5 & 100 \\
\hline 3 & $\begin{array}{l}\text { I see provision of instruction does not engage students } \\
\text { with physical disabilities. }\end{array}$ & 4 & 80 & 1 & 20 & 5 & 100 \\
\hline \multirow[t]{2}{*}{4} & $\begin{array}{l}\text { I believe teachers do not encourage you to participate } \\
\text { in the class like your peers without disability. }\end{array}$ & 3 & 60 & 2 & 40 & 5 & 100 \\
\hline & Average & 3.25 & 65 & 1.75 & 35 & 5 & 100 \\
\hline
\end{tabular}

Table 4. Family and guardians as factors for absenteeism.

\begin{tabular}{|c|c|c|c|c|c|c|c|}
\hline \multirow{3}{*}{ S. No } & \multirow{3}{*}{ Item } & \multicolumn{4}{|c|}{ Response } & \multirow{2}{*}{\multicolumn{2}{|c|}{$\begin{array}{c}\text { Total } \\
\text { Response }\end{array}$}} \\
\hline & & \multicolumn{2}{|c|}{ Agree } & \multicolumn{2}{|c|}{ Disagree } & & \\
\hline & & $\mathrm{F}$ & $\%$ & $\mathrm{~F}$ & $\%$ & $\mathrm{~F}$ & $\%$ \\
\hline 1 & My parents do have lack of knowledge about my disability. & 4 & 80 & 1 & 20 & 5 & 100 \\
\hline 2 & I have parents with low level of economic status. & 3 & 60 & 2 & 40 & 5 & 100 \\
\hline \multirow[t]{2}{*}{3} & My parents do not support me in many things. & 2 & 40 & 3 & 60 & 5 & 100 \\
\hline & Average & 3 & 60 & 2 & 40 & 5 & 100 \\
\hline
\end{tabular}

Table 5. Rule and regulations of the school as factor for absenteeism.

\begin{tabular}{|c|c|c|c|c|c|c|c|}
\hline \multirow{3}{*}{ S. No } & \multirow{3}{*}{ Items } & \multicolumn{4}{|c|}{ Responses } & \multirow{2}{*}{\multicolumn{2}{|c|}{$\begin{array}{c}\text { Total } \\
\text { Response }\end{array}$}} \\
\hline & & \multicolumn{2}{|c|}{ Agree } & \multicolumn{2}{|c|}{ Disagree } & & \\
\hline & & $\mathrm{F}$ & $\%$ & $\mathrm{~F}$ & $\%$ & $\mathrm{~F}$ & $\%$ \\
\hline 1 & $\begin{array}{l}\text { When you are late the school does not allow } \\
\text { you to enter to the school compound. }\end{array}$ & 4 & 80 & 1 & 20 & 5 & 100 \\
\hline \multirow[t]{2}{*}{2} & $\begin{array}{l}\text { The school did not encourage you to participate } \\
\text { in different clubs and issues. }\end{array}$ & 3 & 60 & 2 & 40 & 5 & 100 \\
\hline & Average & 3.5 & 70 & 1.5 & 30 & 5 & 100 \\
\hline
\end{tabular}

Table 6. The attitude of peers and guards as factors for absenteeism.

\begin{tabular}{|c|c|c|c|c|c|c|c|}
\hline \multirow{3}{*}{ S. No } & \multirow{3}{*}{ Items } & \multicolumn{4}{|c|}{ Responses } & \multirow{2}{*}{\multicolumn{2}{|c|}{$\begin{array}{c}\text { Total } \\
\text { Response }\end{array}$}} \\
\hline & & \multicolumn{2}{|c|}{ Agree } & \multicolumn{2}{|c|}{ Disagree } & & \\
\hline & & $\mathrm{F}$ & $\%$ & $\mathrm{~F}$ & $\%$ & $\mathrm{~F}$ & $\%$ \\
\hline 1 & Your class mates do not play with you. & 4 & 80 & 1 & 20 & 5 & 100 \\
\hline 2 & Your classmates insult you using bad words. & 2 & 40 & 3 & 60 & 5 & 100 \\
\hline \multirow[t]{2}{*}{3} & $\begin{array}{l}\text { Guards of the school do not allow you to enter the campus of the } \\
\text { school when you are late. }\end{array}$ & 3 & 60 & 2 & 40 & 5 & 100 \\
\hline & Average & 3 & 60 & 2 & 40 & 5 & 100 \\
\hline
\end{tabular}

Nevertheless, the onset of all most all 4 (80\%) of the student participants of this study's onset of disability was after birth. This sends us a message that the impairment of the students was preventable with necessary early intervention mechanisms of disability either by parents and or health care professionals. Besides, the educational 
Table 7. Teachers' rating on infrastructure of the school as factor of absenteeism.

\begin{tabular}{|c|c|c|c|c|}
\hline S. No & Item & Response & $\mathrm{F}$ & $\%$ \\
\hline \multirow{3}{*}{1} & Do vou think the infrastructure of the school & Yes & 5 & 62.5 \\
\hline & has an impact up on the students' with & No & 3 & 37.5 \\
\hline & & Total & 8 & 100 \\
\hline
\end{tabular}

Table 8. Teachers' rating on the magnitude of absenteeism of the students with physical impairments of the school.

\begin{tabular}{|c|c|c|c|c|}
\hline S. No & Item & Response & $\mathrm{F}$ & $\%$ \\
\hline \multirow{5}{*}{1} & \multirow{5}{*}{$\begin{array}{l}\text { What do you think is the range of students } \\
\text { with physical impairments absenteeism } \\
\text { from the school? }\end{array}$} & Very high & 1 & 12.5 \\
\hline & & High & 4 & 50 \\
\hline & & Medium & 2 & 25 \\
\hline & & Low & 1 & 12.5 \\
\hline & & Total & 8 & 100 \\
\hline
\end{tabular}

level of the majority 4 (80\%) of the parents of the students with physical impairment are primary complete. The worst is, the majority 4 (80\%) of the parents of the student participants are poor. So it is consistent finding with studies reviewed for this study. For example, students, with poor parents are exposed for absenteeism and engaged in different labor tasks whenever they get before finishing their school. To this end, [24] describes that the majority of absenteeism of students with physical impairment come from poor homes

As clearly depicted in Table 2, 6 (75\%) of the teacher participants are males and all 8 (100\%) of the teacher participants have rich experiences of teaching. However, the qualifications of the teachers all in all $8(100 \%)$ is not in special needs education. That means, the teachers do not know anything about special needs of children with special needs including children with physical impairment of the study. This finding is similar with findings reviewed for this study. For instance, [35] found out that the major reasons replied by students for their absenteeism were poor teaching (23\%), timing of the lesson (23\%) and poor quality of the lesson content (9\%).

As clearly depicted in Table 3, the majority (65\%) of the students with physical impairment have attributed their absenteeism from school to the negative attitude of teachers disengaging instructional provision. Studies also support this finding. For example, [36] underlined that students have poor or conflicting relationships with teacher will avoid school in order to avoid their teacher. From this it can be said teacher's positive attitude and well organized provision of instruction which meets the needs of learners can improve the student's regular class room attendance. On the contrary however, (35\%) students with physical disabilities did not agree on the teachers negative attitude and provision of instruction which meets learners and did not affect them to attend their classes. All agree in the interview session that their teachers did not have knowledge in special needs education and teachers have negative attitude towards disability. The latter may affect the feelings of the children with physical impairment too much; starting from feeling of negative attitude towards their disability and to helplessness in their education not to see brighter future.

As clearly put in Table 4, (60) 3 students with physical disabilities agree that lack of knowledge of parents and low economic status has a great effect on their education. This indicates low educational level of parents and low economic status can affect negatively the children not to attend their education properly. This, finding is consistent with similar findings reviewed for this study. For example, in one study in America it was found out that lack of guidance or parental supervision, domestic violence, poverty, drug or alcohol abuse in the home, lack of awareness of attendance laws, and differing attitudes toward education [29]. [30] argued that family obligations also make some students not to go to schools.

As Table 5 shows (70) 3.5 students with disabilities have responded that the school's rules and regulations did not allow students with physical impairment to enter to class when coming late and no special support is given to them. We can argue that when students are not allowed to enter to class when they are late due to their disabilities they will lose their interest to their education. Coupled with the absence of special support from the school, the continuation and their success in their education is under question. This is findings is also consistent 
with findings reviewed for this study. For instance, [34] concluded that harsh school rules and regulations could cause absenteeism that is; corporal punishment, families where students prepare themselves for school and parent to work. [11] stressed that schools, their curricula, and the strength of sanctions against chronic absenteeism are also contributing causes to students' absenteeism in schools. [13] [33] concluded that lack of challenging course work and curriculum are some of the factors for student absenteeism.

As shown in Table 6, (60\%) 3 students with physical impairment stated that their peers are not playing with them though they are not always abusive. if that is the case, the students with physical impairment in the school are said to be not entertaining the social life with their peers. So, it is possible to argue that the latter adult life of the students with physical impairment is under question.

Generally, as we interview students with physical disabilities about those factors that cause of absenteeism they stated the following the classroom situation, teacher's attitude, parental less understanding about disability, fear of traffic accident as the school is very close to the main road (especially when to come to school and go to home), distance from school, poor economy of parents and non involving instructional activities of teacher's in meeting their needs and learning styles. The preceding mentioned factors have been repeatedly mentioned by the students as the main factors for their absenteeism.

The participants stated also in the open ended questionnaire to minimize their absenteeism their parents and the school teachers come together and discuss on the solutions. Besides, they suggested that training should be prepared for teachers and students of the school to have positive relationship and attitude. Especially for the teachers to use appropriate methodology that fits to the learning styles of students with physical disabilities.

As clearly seen from Table 7, the majority 5 (62.5\%) of the teachers revealed that the infrastructure of the school has a great effect on students with physical impairment absenteeism from school. If there is no well organized and conducive infrastructure in the school in the future the students with physical impairments will continue to be absent from school. Not only the participant students alone but other students with special needs too. On the contrary however, 3 (37.5\%) of the teachers said the school infrastructure will not have a negative impact on the students absenteeism.

As depicted in Table 8, half of (50\%) of the teachers of the study revealed that the range of absenteeism of students with physical impairments is high due to various factors. Whereas, 1 (12.5\%) teacher participant described the range of absenteeism in not high, but low like other students without physical impairments. but, it is possible to argue that above half of the respondents agreed and wrote in the open-ended questionnaire the range of absenteeism is moderate to high. Generally speaking, as literatures show for example [29] school size and attitudes of teachers, other students, and principals and unit leaders and inflexibility in meeting the diverse cultural and learning styles of the students could be factors for absenteeism. Schools often have inconsistent procedures in place for dealing with chronic absenteeism and may not have meaningful consequences available for truant youth (e.g., out of school suspension), the absenteeism of the student participants of the study are attributed to various factors that has been found out in this study.

\section{Summary, Conclusion and Recommendation}

\subsection{Summary}

Education is vital if students with disabilities are going to participate in societies and get employment opportunities. Students with disabilities are less likely to attend schools than their peers due to environmental factors related their condition and other factors including attitude of parents, teachers and peers.

This research tried to investigate the major factors that affect students with physical impairments absenteeism from school in Hedar 11 General Secondary School in Gondar town Amhara Regional State of Ethiopia. To achieve the objective the researchers formulated the following leading question:

What are the major factors that affect students with physical impairment absenteeism from school?

The purpose of this study was to create awareness for classroom teachers; school principal, parents, governmental and non-governmental organizations about those factors that are attributed for absenteeism of students with physical impairments from school and help them look for various alternative solutions to make the students participants attend their education regularly and be benefited from it. Also, pave fertile ground for other researchers to move on this type of research further.

Nevertheless, to answer the basic question of this research, the researchers through available sampling took 5 students of the school and 8 teachers of the school through random sampling via lottery system. To collect data 
questionnaire and interview were used as a main data collection instruments. The questionnaire was closed and open indeed item, where as the interview guide session was unstructured interview.

Data from questionnaire was analyzed through frequency, percentage and average, where as data from interview were analyzed thematically. The result of the study can be put as follows:

$\checkmark$ Teachers are not playing their roles if teachers exert their efforts they can minimize the absenteeism of students with physical impairment by making the school rules and regulations clear and giving instructional and moral support.

$\checkmark$ The type of delivery of instruction that is delivered by the teachers of students with physical disabilities lag behind the need and learning styles of the students.

$\checkmark$ The economic status, parental educational level, distance from and to the school, attitude of parents and students are the major causes of absenteeism.

\subsection{Conclusions}

Based on the findings the following conclusions were drawn:

The major factors of absenteeism from the school for students with physical impairments were low economic status of parents, poor infrastructure of the school, negative attitude of teachers, students without disabilities and lack of support and poor instructional delivery of the teachers.

If immediate solution is not taken by the school community, parents and stakeholders, the likeliness of better academic performance and sustainability of the education of students with physical impairments are questionable.

\subsection{Recommendation}

On the basis of the findings of the study, the following recommendations were made assuming that it will be feasible solutions to the problems under consideration:

$\checkmark$ Teachers, school administrators and other professionals should make a great effort in handling students with physical impairments and give the necessary assistance when they encounter problems;

$\checkmark$ Teachers, school administrators and other educational personal should build a close relationship with parents of students with physical impairments and try to make parents be aware of education and its value; and

$\checkmark$ The school can inform parents, teachers and students by preparing dramas, theaters, etc, which clearly show the effects absenteeism on pupil's progress at school.

\section{Acknowledgements}

We would like to thank the University of Gondar, School of Education and Department of Special Needs Education for providing this research opportunity. Our special gratitude is also extended to Hedar 11 Secondary School and the teachers and student participants of the study for their collaboration to make the research completed on time.

\section{References}

[1] Japan International Cooperation Agency, JICA (2002) Kunibetsu Hinkon Joho Ethiopia (Poverty Information on Ethiopia). Unpublished.

[2] Ministry of Education (2006) Special Needs Education Program Strategy Emphasizing on Inclusive Education to Meet the UPEC and EFA Goals. Master Printing Press, Addis Ababa.

[3] UNESCO (2005) Guidelines for Inclusion: Ensuring Access to Education for All France. UNESCO.

[4] Ministry of Finance and Economic Development Federal Democratic Republic of Ethiopia, MoFED (2012) Assessing Progress towards the Millennium Development Goals. Federal Democratic Republic of Ethiopia. Ethiopia MDGS Report. Addis Ababa, Ethiopia.

[5] Marburger, D.R. (2006) Does Mandatory Attendance Improve Student Performance? The Journal of Economic Education, 37, 148-155. http://dx.doi.org/10.3200/JECE.37.2.148-155

[6] Kamla, R. (2011) Cause and Structural Effects of Student Absenteeism: A Case Study of Three South African Universities. Journal of Social Science, 26, 89-97.

[7] Segal, C. (2008) Classroom Behavior. Journal of Human Resources, 43, 783-814. 
http://dx.doi.org/10.1353/jhr.2008.0024

[8] Lalek, A. (1995) Quality Progress-Fifth Quality in Education Listing. Quality Progress, 28, 27-77.

[9] Rumberger, R.W. (1997) High School Dropouts: A Review of Issues and Evidence. Review of Educational Research, 23, 24-42.

[10] Weller, D.L. (1996) The Next Generation of School Reform. Quality Progress, 29, 65-70.

[11] Williams, L.L. (2000) Student Absenteeism and Truancy. Technologies and Interventions to Reduce Chronic Problems among School-Age. Journal of Children, 7, 23-34.

[12] Barker, D. and Jansen, J. (2000) Using Groups to Reduce Elementary School Absenteeism. Social Work in Education, 22, 46-53.

[13] Lotz, R. and Lee, L. (1999) Sociability, School Experience and Delinquency. Youth \& Society, 31, $199-224$.

[14] Mayer, G. and Mitchell, L. (1996) A Drop-Out Prevention Programme for At-Risk High School Students: Emphasising Consulting to Promote Positive Classroom Climates. Educational Treatment of Children, 16, 135-138.

[15] Ajiboye, J.O. and Tella, A. (2006) Class Attendance and Gender Effects on Undergraduate Students’ Achievement in a Social Studies Course in Botswana. Essays in Education, 18, 1-14.

[16] Ledman, R.E. and Kamuche, F. (2003) Improving Student Attendance. Academic Exchange Quarterly, 6.

[17] Enomoto, E. (1997) Negotiating the Ethics of Care and Justice. Educational Administration Quarterly, 33, 351-370. http://dx.doi.org/10.1177/0013161X97033003005

[18] Edward, J.F. (2005) A Study of Attendance and Its Effects on Academic Achievement in Alliance Public Schools. ETD Collection for University of Nebraska-Lincoln, Paper AAI3180799. http://wps.fep.up.pt/wps/wp503.pdf

[19] Ziegler, C.W. (1972) School Attendance as a Factor in School Progress. AMS Press, Inc., New York.

[20] DeKalb, J. (1999) Student Truancy. (Report No. EDO-EA-99-1), ERIC Document Reproduction Service No. ED429334, Office of Educational Research and Improvement, Washington DC.

[21] Tirussew, T. (1999) Inclusion of Children with Disabilities in Regular Schools: Challenges and Opportunities. The Ethiopian Journal, 19, 29-64.

[22] Taylor, R. and Sternberg, L. (1989) The Role of Information Processing in the Education of Learning Disordered Children. Prentice Hall, Englewood Cliffs.

[23] Garwood, S.G. (1983) Educating Young Handicapped Children. A Developmental Approach. Aspen Publication, Rockville.

[24] Ysseldyke, J.E. and Algozzine, B., Eds. (1995) Special Education: A Practical Approach to Teachers. 3rd Edition, Houghton, Mufflin Company, Boston.

[25] Heward, W.L. and Orlansky, M.D. (1988) Exceptional Children: An Introductory Survey of Special Education. 3rd Edition, Merrill Publishing Company, Melbourne.

[26] Gallgher, G. and Anastain, N. (1976) Educating Exceptional Children. 3rd Edition, Merril Publishing Company, Columbus.

[27] Rothman, S. (2001) School Absence and Student Background Factors: A Multilevel Analysis. International Education Journal, 2, 59-68.

[28] Credé, M., Roch, S.G. and Kieszczynka, U.M. (2010) Class Attendance in College: A Meta-Analytic Review of the Relationship of Class Attendance with Grades and Student Characteristics. Review of Educational Research, 80, 272 295. http://dx.doi.org/10.3102/0034654310362998

[29] US Department of Education (2002) No Child Left behind Act of 2001. http://www.ed.gov./legislation/ESEA02/beginning.html

[30] Balfanz, R. and Byrnes, V. (2012) Chronic Absenteeism: Summarizing What We Know from Nationally Available Date. Jhons Hopkins University Center for Social Organization of Schools, Baltimore.

[31] Rohrman, D. (1993) Com Bating Truancy in Our Schools-A Community Effort. NASSP (National Association of Secondary School Principals) Bulletin, 76, 40-51.

[32] Tayetrman, M.J. (1968) Truancy. University of London Press Ltd., London.

[33] Kilpatrcik, P. (1996) Missing School. Youth Studies, 15, 19-22.

[34] Shahzada, G., Ghazi, S.R., Nawaz, H. and Khan, A. (2011) Causes of Absenteeism from Schools at Secondary Level. Mediterranean Journal of Social Sciences, 2, 291-298.

[35] Fleming, N. (1995) Attendance. Why Don’t They Attend? Macmillan Press, London.

[36] Teasley, M.L. (2004) Absenteeism and Truancy. Children and Schools, 26, 117-127. 


\section{Appendix A}

\section{University of Gondar}

School of Education

Department of Special Needs Education

Questionnaire to teachers

This questionnaire was prepared for teachers and the main objective of it was to investigate those factors that are attributed for absenteeism of students with physical impairments. The study can be successful if your honest participation is secured. The study is relevant and can be more relevant when the study findings are reported to the concerned bodies.

Thank you in advance!!

Your background information: please write about your background information as in below.

1. Sex: Male Female

2. Teaching experience: 5 years

3. Felid of study: Special needs education 6 to15 years 16 and above years

Please, select either of the following options related to the questions.

\begin{tabular}{|c|c|c|c|c|c|}
\hline S.N. & Item & \multicolumn{4}{|c|}{ Responses } \\
\hline 1. & $\begin{array}{l}\text { Do you think the infrastructure of the } \\
\text { school has an impact up on the students' } \\
\text { attendance? }\end{array}$ & & & & \\
\hline 2. & $\begin{array}{l}\text { What is the range of students with } \\
\text { physical impairments absenteeism } \\
\text { from the school? }\end{array}$ & Very high & High & Medium & Low \\
\hline
\end{tabular}

\section{Appendix B}

\section{University of Gondar}

School of Education

Department of Special Needs Education

Questionnaire to for students

This questionnaire was prepared for students and the main objective of it was to investigate those factors that are attributed for absenteeism of students with physical impairments. The study can be successful if your honest participation is secured. The study is relevant and can be more relevant when the study findings are reported to the concerned bodies.

Thank you in advance!!

Your background information: please write about your background information as in below.

1. Sex: Male Female

2. Grade level: $9^{\text {th }}$ grade

3. On set of disability: Before birth $10^{\text {th }}$ grade

4. Parent's educational level: primary complete After birth

5. Parent's economic status: Rich Secondary complete Degree and above

Please, select either of the following options related to the questions.

\begin{tabular}{cr}
\hline S. No & Item \\
\hline 1 & I observe negative attitude of teachers towards students with physical disabilities. \\
3 & I am unable to get special support from teachers. \\
4 & I see provision of instruction does not engage students with physical disabilities. \\
\hline
\end{tabular}




\section{Continued}

\section{5}

6

7

8

9

10

11

12

13

My parents do have lack of knowledge about my disability.

I have parents with low level of economic status.

My parents do not support me in many things.

When you are late the school does not allow you to enter to the school compound.

The school did not encourage you to participate in different clubs and issues.

Your class mates do not play with you.

Your classmates insult you using bad words.

Guards of the school do not allow you to enter the campus of the school when you are late.

Do you think the infrastructure of the school has an impact up on the students' with physical disabilities attendance?

\section{Appendix C}

\section{University of Gondar}

School of Education

Department of Special Needs Education

Interview guide questions to students with physical disabilities

1. What are the factors that force you be absent from school? Can you explain them in detail

2. Do you think the school and the schools' community can be taken as factors for your absenteeism from school? How?

3. Do you think the teachers attitude and things related to teachers can be associated for your absence?

4. How far is the school from your home? Can it be rated as challenging as factor for your absenteeism? 